\title{
KEPUTUSAN PEMBELIAN ULANG DITINJAU DARI EXPERIENTAL MARKETING DAN KEPUASAN PELANGGAN PADA THE HIDDEN PLACE SURAKARTA
}

\author{
Adinia Intan Pratiwi, Siti Maryam, Ratna Damayanti \\ Fakultas Ekonomi Manajemen Universitas Islam Batik Surakarta \\ Email : adiniaintanp@gmail.com
}

\begin{abstract}
This study aims to determine the effect of repurchase decisions in terms of experiential marketing and customer satisfaction at The Hidden Place Surakarta. This type of research is descriptive quantitative. This study uses primary data collected using a questionnaire as a research instrument. The sample research method used was non probability sampling with purposive sampling technique. The respondents of this study were consumers who made at least two purchases. respondents who used were 100 respondents. The data analysis technique used is path analysis. The results of the study can be concluded that experiential marketing has a positive and significant effect on repurchase decisions, experiential marketing has a positive and significant effect on customer satisfaction, customer satisfaction has a positive and significant effect on repurchase decisions, experiential marketing has a positive and significant effect on repurchase decisions through customer satisfaction..
\end{abstract}

Keywords : Experiential marketing, customer satisfaction, repurchase decisions

\section{PENDAHULUAN}

Indonesia dikenal sebagai negara agraris dengan salah satu komoditasnya kopi. Saat ini kopi menjadi produk yang berkembang pesat. Berdasarkan Pusat Data dan Sistem Informasi Pertanian Kementerian Pertanian, konsumsi kopi nasional sepanjang periode 2016 sampai dengan 2021 diprediksi tumbuh rata-rata 8,22\% pertahun. Pada 2021, pasokan kopi diprediksi mencapai 795 ribu ton dengan konsumsi 370 ribu ton (katadata.co.id).

Pembelian ulang terjadi ketika konsumen merasa bahwa produk yang dibeli telah sesuai kriteria yang diinginkan. Konsumen akan melakukan pembelian kembali sebagai bentuk pertimbangan terkait konsumsi produk yang dipengaruhi oleh lingkungan sekitarnya seperti kepuasan konsumen dan experiental marketing (Wijaya \& Suparna, 2017).

Barimbing \& Sari (2015) Membangun hubungan yang langgeng dengan konsumen dapat dilakukan melalui 5 aspek dalam experiental marketing diantaranya panca indera (sense), perasaan (feel), pemikiran (think), tindakan (act), relasi (relate). Experiental Marketing berusaha menghadirkan pengalaman unik dan mengesankan bagi konsumen, sehingga konsumen tidak hanya akan melakukan pembelian ulang, tetapi akan menyebarkan informasi produk kepada orang lain (Indarwati dan Tiarawati, 2015).

Tujuan sebuah bisnis adalah mendapatkan keuntungan dengan memberikan rasa puas terhadap konsumen. Konsumen yang merasa puas terhadap produk cenderung akan membeli dan mengkonsumsi kembali di kemudian hari. Kepuasan dalam hal ini menjadi faktor kunci dalam melakukan pembelian ulang bagi konsumen (Kurniawati, et al, 2018).

Solo memiliki persebaran coffeshop yang cukup merata. The Hidden Place menjadi salah satu coffeshop yang ikut mengambil peluang bisnis yang trend saat ini. Konsep garden yang luas dan penyediaan area indoor outdoor membuat berbeda dari para pesaingnya. Konsumen yang datang dapat berinteraksi dan melihat secara langsung bagaimana para barista meracik kopi. Namun masih ada konsumen yang mengeluhkan beberapa masalah yang harus diperhatikan oleh pihak The Hidden 
Place diantaranya papan penunjuk lokasi yang tidak tersedia, konsumen merasa harga yang ditawarkanpun cukup mahal dan tidak menyasar untuk semua kalangan.

Berdasarkan hasil pra survei yang dilakukan peneliti terhadap 50 konsumen yang pernah berkunjung dan mengkonsumsi produk pada The Hidden Place, responden yang menyatakan berminat melakukan pembelian ulang sebesar $42 \%$ atau sebanyak 21 orang, sedangkan responden yang menyatakan tidak berminat melakukan pembelian ulang sebesar 58\% atau sebanyak 29 orang. Hal ini membuktikan bahwa masih adanya suatu permasalahan yang membuat konsumen tidak berminat melakukan pembelian ulang pada The Hidden Place Surakarta.

Berdasarkan uraian latar belakang di atas, maka penelitian ini bermaksud untuk mengetahui pengaruh experiental marketing terhadap keputusan pembelian ulang. Mengetahui pengaruh experiental marketing terhadap kepuasan pelanggan. Mengetahui pengaruh kepuasan pelanggan terhadap keputusan pembelian ulang. Mengetahui pengaruh experiental marketing terhadap keputusan pembelian ulang melalui kepuasan pelanggan pada The Hidden Place Surakarta.

\section{LANDASAN TEORI}

A. Keputusan Pembelian Ulang

Wijaya \& Subagio (2014) mengatakan bahwa keputusan pembelian ulang adalah sikap yang timbul sebagai bentuk respon terhadap obyek yang menunjukan keinginan konsumen untuk melakukan pembelian ulang. Indikator keputusan pembelian ulang menurut Hartati, et al. (2017) memiliki beberapa unsur diantaranya, melakukan pembelian ulang, merekomendasikan kepada orang lain, konsumen setia pada produk.

\section{B. Experiental Marketing}

Yufizar \& Rahayu (2017) experiential marketing adalah sebuah pendekatan pemasaran yang melibatkan emosi dan perasaan konsumen dengan menciptakan pengalaman-pengalaman positif yang tidak terlupakan sehingga konsumen mengkonsumsi dan fanatik terhadap produk. Experiential marketing menurut Barimbing \& Sari (2015) dapat diukur menggunakan lima faktor yaitu:

1) Sense

strategi pemasaran bagaimana memunculkan pengalaman melalui panca indera pelanggan seperti, mata, telinga, kulit, lidah dan hidung.

2) Feel

Suatu usaha pemasar guna menyentuh emosi konsumen dengan memberi perhatian kecil, sehingga akan menciptakan suasana hati yang menggembirakan sesuai harapan pemasar.

3) Think

Suatu pengalaman yang melibatkan konsumen dalam pemikiran yang kreatif sehingga akan berdampak pada penilaian ulang terhadap suatu produk yang ditawarkan perusahaan.

4) Act

Suatu usaha menciptakan persepsi pelanggan terhadap produk yang akan mempengaruhi perilaku, gaya hidup dan interaksi konsumen.

5) Relate

Upaya dalam mempengaruhi pelanggan yang merupakan penggabungan dari semua aspek sense, feel, think, dan act melalui komunikasi sehingga pelanggan akan membentuk suatu komunitas. 


\section{Kepuasan Pelanggan}

Wijaya \& Subagio (2014) mengatakan bahwa kepuasan pelanggan merupakan sebuah perasaan puas atau kecewa pelanggan yang dihasilkan dari perbandingan antara kinerja sebuah produk yang diterima dengan harapan pelanggan. Manfaat kepuasaan pelanggan menurut Sugianto \& Sugiharto (2013) diantaranya, hubungan perusahaan dan para pelanggannya menjadi harmonis, memberikan dasar yang baik bagi pembelian ulang. dapat mendorong terciptanya kesetiaan pelanggan, membentuk rekomendasi dari mulut ke mulut (word of mouth) yang menguntungkan bagi perusahaan, reputasi perusahaan menjadi baik dimata pelanggan, laba yang diperoleh dapat meningkat.

D. Kerangka Pemikiran

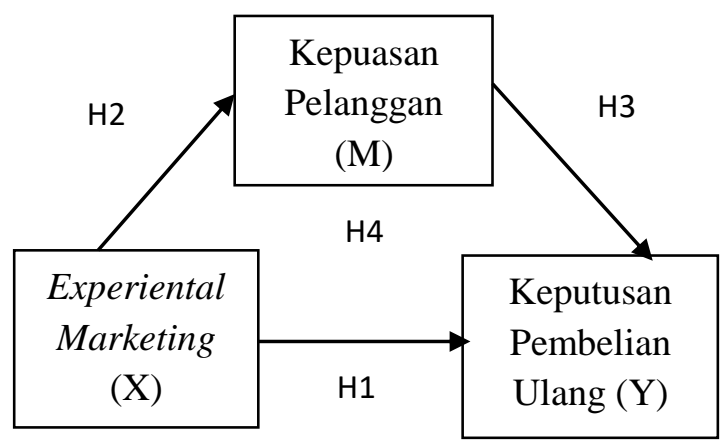

Gambar 1. Kerangka Pemikiran

\section{METODOLOGI PENELITIAN}

Penelitian ini menggunakan metode deskriptif kuantitatif. Metode kuantitatif menekankan analisisnya pada data angka yang diolah dengan metode statistika (Azwar, 2012:5). Penelitian dilakukan di The Hidden Place Surakarta. Populasi dalam penelitian ini yaitu seluruh konsumen yang pernah melakukan pembelian di The Hidden Place Surakarta. Menurut Sugiyono (2015:118) sampel merupakan sebagian dari jumlah dan karakteristik yang dimiliki oleh pulasi. Sampel dalam penelitian ini sebanyak 100 responden. Metode pengumpulan data dengan menggunakan kuesioner. Teknik pengambilan sampel menggunakan teknik non probability sampling dengan metode Purposive sampling dengan pertimbangan konsumen yang telah melakukan pembelian ulang minimal dua kali. Teknik analisis data yang digunakan yaitu uji instrument, uji asumsi klasik, dan analisis path. Menurut Rutherford (1993) analisis path digunakan untuk menganalisa hubungan sebab akibat yang terjadi pada regresi berganda jika variabel eksogen mempengaruhi variabel endogen tidak hanya secara langsung tapi juga secara tidak langsung.

\section{HASIL DAN PEMBAHASAN}

Dilakukan analisis untuk menjawab masalah yang telah dijabarkan sebelumnya. Penelitian ini menggunakan analisis path. Analisis path merupakan teknik pengembangan dari regresi linear berganda. Berikut adalah hasil perhitungan menggunakan analisis path : 
A. Analisis Struktur Jalur

1) Analisis Struktur Jalur Experiental marketing (X) terhadap Keputusan pembelian ulang (Y)

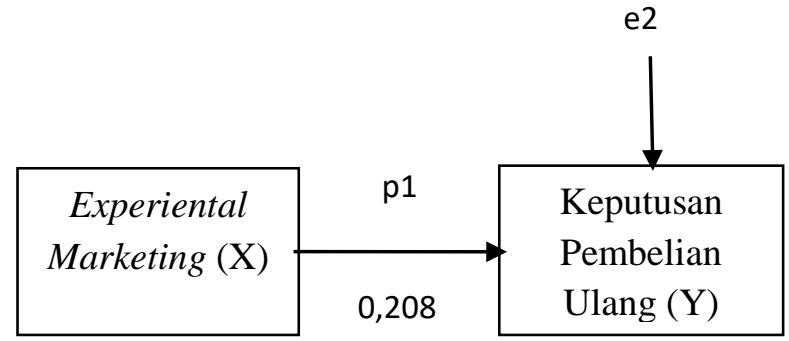

Gambar 2. Struktur Jalur X terhadap Y

Tabel 1

Hasil Analisis Jalur Struktur Pertama

\begin{tabular}{|c|c|c|c|}
\hline Variabel & $\begin{array}{c}\text { Standardized } \\
\text { Coefficients Beta }\end{array}$ & Sig & Keterangan \\
\hline Experiental Marketing & 0,208 & 0,028 & Signifikan \\
\hline
\end{tabular}

Rumus yang digunakan untuk menentukan nilai e2 adalah sebagai berikut :

$$
e 2=\sqrt{\left(1-R^{2}\right)}
$$

$$
\begin{aligned}
& =\sqrt{(1+0,399)} \\
& =0,775
\end{aligned}
$$

Persamaan berdasarkan hasil analisis dapat disusun sebagai berikut :

$\mathrm{Y}=\mathrm{p} 1 \mathrm{X}+\mathrm{e} 2$

$$
Y=0,208 X+0,775
$$

Berdasarkan hasil analisis jalur diketahui bahwa nilai koefisien standardized sebesar 0,208 dan nilai signifikan sebesar 0,028 dengan tingkat kesalahan yang digunakan adalah 0,05. Hasil tersebut memperlihatkan bahwa nilai signifikan sebesar 0,028 $<0,05$ berarti $\mathrm{H} 1$ diterima. hasil tersebut memperlihatkan bahwa Experiental marketing memiliki pengaruh langsung dan signifikan dalam mempengaruhi terbentuknya keputusan pembelian ulang konsumen pada The Hidden Place Surakarta.Nilai koefisien standardized sebesar 0,208 merupakan nilai path atau jalur pada p1.

2) Struktur Jalur Experiental marketing (X) terhadap Kepuasan pelanggan (M)

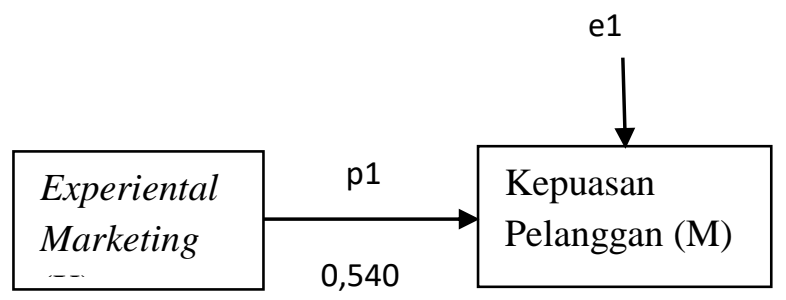

Gambar 3. Struktur Jalur X terhadap M 
Tabel 2

Hasil Analisis Jalur Struktur Kedua

\begin{tabular}{|l|l|l|l|}
\hline Variabel & $\begin{array}{l}\text { Standardized } \\
\text { Coefficients Beta }\end{array}$ & Sig & Keterangan \\
\hline Experiental Marketing & 0,540 & 0,000 & Signifikan \\
\hline
\end{tabular}

Rumus yang digunakan untuk menentukan nilai e1 adalah sebagai berikut :

$$
e 1=\sqrt{\left(1-R^{2}\right)}
$$

$$
\begin{aligned}
& =\sqrt{(1+0,291)} \\
& =0,842
\end{aligned}
$$

Persamaan berdasarkan hasil analisis dapat disusun sebagai berikut :

$$
\begin{aligned}
& \mathrm{M}=\mathrm{p} 2 \mathrm{X}+\mathrm{e} 1 \\
& M=0,540 X+0,842
\end{aligned}
$$

Berdasarkan hasil analisis jalur diketahui bahwa nilai koefisien standardized sebesar 0,540 dan nilai signifikan sebesar 0,000 dengan tingkat kesalahan yang digunakan adalah 0,05. Hasil tersebut memperlihatkan bahwa nilai signifikan sebesar 0,000 $<0,05$ berarti $\mathrm{H} 1$ diterima. Hasil tersebut memperlihatkan bahwa Experiental marketing memiliki pengaruh langsung dan signifikan dalam mempengaruhi terbentuknya kepuasan pelanggan ketika menikmati produk maupun layanan yang diberikan oleh The Hidden Place Surakarta. Nilai koefisien standardized sebesar 0,540 merupakan nilai path atau jalur pada p2.

3) Struktur Jalur Kepuasan pelanggan (M) terhadap Keputusan pembelian ulang (Y)

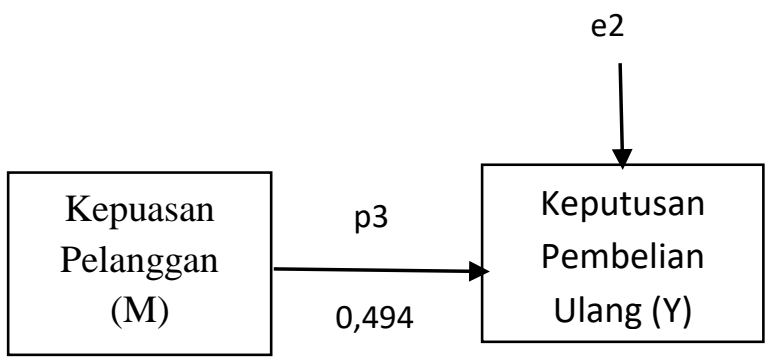

Gambar 4. Struktur Jalur M terhadap Y

Tabel 3

Hasil Analisis Jalur Struktur Pertama

\begin{tabular}{|l|l|l|l|}
\hline Variabel & $\begin{array}{c}\text { Standardized } \\
\text { Coefficients Beta }\end{array}$ & Sig & Keterangan \\
\hline Experiental Marketing & 0,494 & 0,000 & Signifikan \\
\hline
\end{tabular}


Rumus yang digunakan untuk menentukan nilai e2 adalah sebagai berikut :

$$
\begin{aligned}
& =\sqrt{(1+0,399)} \\
& =0,775
\end{aligned}
$$

Persamaan berdasarkan hasil analisis dapat disusun sebagai berikut :

$\mathrm{Y}=\mathrm{p} 3 \mathrm{X}+\mathrm{e} 2$

$Y=0,494 M+0,775$

Berdasarkan hasil analisis jalur diketahui bahwa nilai koefisien standardized sebesar 0,494 dan nilai signifikan sebesar 0,000 dengan tingkat kesalahan yang digunakan adalah 0,05. Hasil tersebut memperlihatkan bahwa nilai signifikan sebesar $0,000<0,05$ berarti $\mathrm{H} 1$ diterima. Hasil tersebut memperlihatkan bahwa kepuasan pelanggan memiliki pengaruh langsung dan signifikan dalam mempengaruhi terbentuknya keputusan pembelian ulang konsumen pada The Hidden Place Surakarta. Nilai koefisien standardized sebesar 0,494 merupakan nilai path atau jalur pada p3.

4) Struktur Jalur Experiental marketing terhadap keputusan pembelian ulang melalui Kepuasan pelanggan

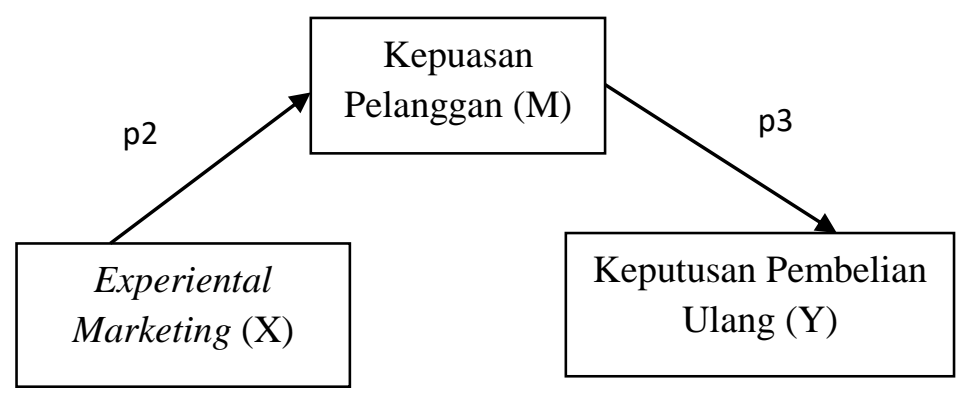

Gambar 5. Struktur Jalur Variabel Mediasi

Menghitung pengaruh mediasi variabel X (Experiental marketing) ke Y (keputusan pembelian ulang) melalui $\mathrm{M}$ (kepuasan pelanggan) dapat dihitung dengan cara mengalikan jalur $\mathrm{X} \rightarrow \mathrm{M}(\mathrm{p} 2)$ dengan jalur $\mathrm{M} \rightarrow \mathrm{Y}(\mathrm{p} 3)$. Adapun rumus sebagai berikut :

$X-Y$ melalui $M=p 2 \times p 3$

$$
\begin{aligned}
& =0,494 \times 0,540 \\
& =0,267
\end{aligned}
$$

Setelah diketahui hasil perhitungannya, maka dapat diketahui pengaruh total yang diberikan oleh variabel experiental marketing (X) terhadap keputusan pembelian ulang (Y) melalui perhitungan pengaruh langsung experiental marketing $(\mathrm{X})$ terhadap keputusan pembelian ulang $(\mathrm{Y})$ ditambah dengan pengaruh tidak langsung Experiental marketing $(X)$ terhadap Kepuasan pelanggan melalui Keputusan pembelian ulang. Rumus sebagai berikut :

$$
\begin{aligned}
X-Y & =p 1+(p 2 \times p 3) \\
& =0,208+(0,540 \times 0,494) \\
& =0,208+0,267
\end{aligned}
$$


$=0,475$

Berdasarkan hasil perhitungan diatas diketahui bahwa nilai pengaruh langsung 0,208 dan pengaruh tidak langsung sebesar 0,267 yang berarti bahwa nilai pengaruh tidak langsung lebih besar dibandingkan dengan nilai pengaruh langsung 0,208 < 0267 berarti H1 diterima. Hasil tersebut menunjukkan bahwa secara tidak langsung Experiental marketing terhadap Keputusan pembelian ulang melalui kepuasan pelanggan memiliki pengaruh yang signifikan.

Hasil koefisien jalur dapat digambarkan sebagai berikut :

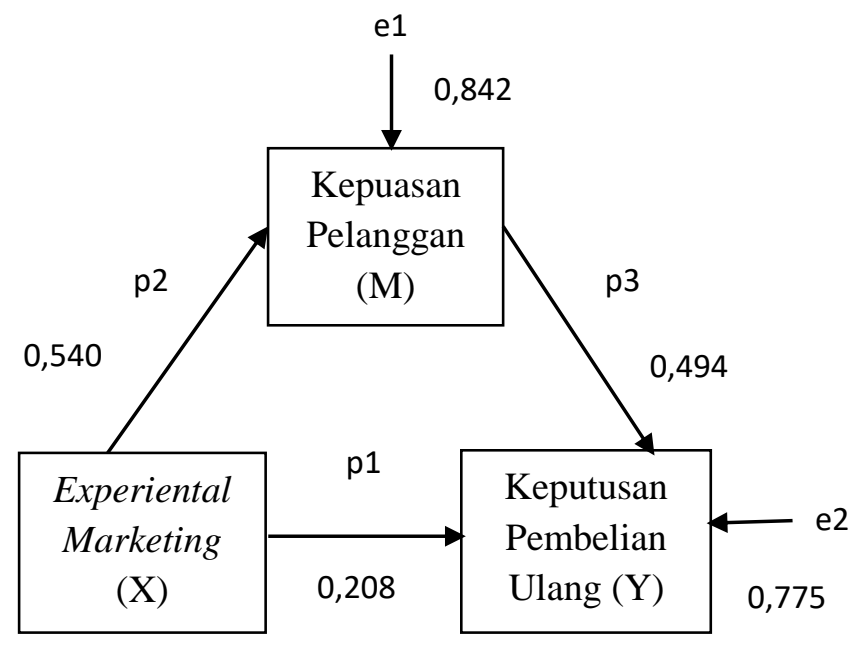

Gambar 6. Model Diagram Jalur Akhir

\section{KESIMPULAN}

Berdasarkan hasil analisis dari pembahasan, maka dapat disimpulkan sebagai berikut :

1) Experiental marketing berpengaruh positif dan signifikan terhadap keputusan pembelian ulang. Hal tersebut berarti bahwa semakin baik experiental marketing yang diberikan maka, semakin tinggi keputusan pembelian ulang.

2) Experiental marketing berpengaruh positif dan signifikan terhadap kepuasan pelanggan. Hal tersebut berarti semakin baik experiental marketing maka, semakin baik kepuasan pelanggan.

3) Kepuasan pelanggan berpengaruh positif dan signifikan terhadap keputusan pembelian ulang. Hal tersebut berarti semakin tinggi kepuasan yang dirasakan pelanggan maka, semakin tinggi keputusan pembelian ulang.

4) Experiental marketing berpengaruh positif dan signifikan terhadap keputusan pembelian ulang melalui kepuasan pelanggan.

\section{SARAN}

1) The Hidden Place Surakarta sebaiknya tetap mempertahankan dan menjaga kualitas experential marketing yang sudah ada, dalam rangka peningkatan kepuasan pelanggan yang akan berdampak pada keputusan konsumen untuk melakukan pembelian ulang. 
2) The Hidden Place memberikan inovasi yang berkelanjutan dan stimulus lainnya untuk memberikan pengalaman konsumsi kepada konsumen mengenai konsep pelayanan yang kuat dan unik.

3) The Hidden Place Surakarta dapat menjadi media untuk mengedukasi konsumen mengenai manfaat dan keunikan kopi dari beberapa daerah di Indonesia.

\section{DAFTAR PUSTAKA}

Azwar, S. (2012). Metode Penelitian. Yogyakarta: Pustaka Pelajar.

Barimbing, C. A., \& Sari, D. (2015). Pengaruh Experiental Marketing Terhadap Kepuasan Pelanggan (Studi pada Pelanggan Mujigae Resto Ciwalk Bandung). 2(1), 770-777.

Hartati , Suardi, \& Santi , I. N. (2017). Pengaruh Kualitas Produk Terhadap Keputusan Pembelian Ulang Sabun Mandi Merek Shinzui di Kota Palu. 4(3), 289-298.

https://databoks.katadata.co.id/datapublish/2018/07/31/2021-konsumsi-kopi-indonesia diprediksimencapai-370-ribu-ton. Diakses pada tanggal 25 November 2019 pukul 14.08

Indarwati, T., \& Tiarawati, M. (2015). Strategi Pemasaran Melalui Experience dan Emotional Marketing Terhadap Kepuasandan Loyalitas Pelanggan Di J.CO Donuts \& caffee Surabaya. 15(1), 102-117.

Kurniyawati, W., Rahadhin, M. D., \& Wibowo, E. (2018). Pengaruh Experiental Marketing Terhadap Pembelian Ulang Dengan Kepuasan Pelanggan Sebagai Variabel Mediasi (Survei pada Konsumen Wedangan di Mojosongo Surakarta). 18(1), 13-23.

Sarwono, J. (2012). Metode Riset Skripsi Pendekatan Kuantitatif Menggunakan Prosedur SPSS . Jakarta: PT Alex Media Komputindo.

Sugianto, J., \& Sugiharto, S. (2013). Analisa Pengaruh Service Quality, Food Quality, Danprice Terhadap Kepuasan Pelanggan Restoran Yung Ho Surabaya. 1(2), 1-10.

Sugiyono. (2010). Metode Penelitian Bisnis (Pendekatan Kuantitatif, Kualitatif, dan R\&D). Bandung: Alfabeta.

Sugiyono. (2015). Metode Penelitian Pendidikan (Pendekatan Kuantitatif, Kualitatif, dan R\&D). Bandung: Alfabeta.

Wijaya , A., \& Subagio, H. (2014). Analisis Pengaruh Experiential Marketing Terhadap Repeat Purchase Dengan Customer Satisfaction Sebagai Mediating Variable Di De Mandailing Cafe UC Boulevard Surabaya. 2(1), 1-9.

Wijaya, P. E., \& Suparna, G. (2017). Peran Customer Satisfaction Memediasi Pengaruh Experiental Marketing Terhadap Repeat Purchase pada Mangsi Coffee Di Denpasar. 6(10), 5432-5459.

Yufizar, A. F., Rastuti, S., \& Rahayu, D. D. (2017). Pengaruh Experiental Marketing dan Brand Trust Terhadap Kepuasan Konsumen dan Loyalitas Pelanggan Hotel Grand Jatra Pekanbaru. 4(1), 939-953. 